\title{
Translational Research in Central Nervous System Drug Discovery
}

\author{
Orest Hurko and John L. Ryan \\ Translational Research, Wyeth, Collegeville, Pennsylvania 19426
}

\begin{abstract}
Summary: Of all the therapeutic areas, diseases of the CNS provide the biggest challenges to translational research in this era of increased productivity and novel targets. Risk reduction by translational research incorporates the "learn" phase of the "learn and confirm" paradigm proposed over a decade ago. Like traditional drug discovery in vitro and in laboratory animals, it precedes the traditional phase 1-3 studies of drug development. The focus is on ameliorating
\end{abstract}

the current failure rate in phase 2 and the delays resulting from suboptimal choices in four key areas: initial test subjects, dosing, sensitive and early detection of therapeutic effect, and recognition of differences between animal models and human disease. Implementation of new technologies is the key to success in this emerging endeavor. Key Words: CNS, drug discovery, translational research, biomarkers, proteomics, imaging.

\section{INTRODUCTION}

In the pharmaceutical industry, translational research refers specifically to those activities conducted to bridge the gap between drug discovery in animals and drug development in human patients. The need for such activities has been driven by two major changes in drug discovery: increased productivity and the focus on novel drug targets not yet pharmacologically proven in man. Availability of the complete genome sequence of humans and the partial ability to deduce probable gene function informatically and experimentally has increased the number of potential drug targets from the 500 or so that underlie our current pharmacopeia ${ }^{1}$ to potentially tens of thousands. Only a small minority of these potential targets have been pharmacologically proven in human disease. Combinatorial chemistry and high-throughput screening ensure that small molecules interacting with a substantial majority of these potential drug targets can be devised in a matter of few years and optimized by increasingly standardized methods. Humanized monoclonal antibodies provide still another source of readily developed therapeutic agents against virtually any cloned protein target, whether or not its function in human disease is understood. As a result, the sheer volume of

Address correspondence and reprint requests to Orest Hurko, Assistant Vice-President, Clinical Discovery, Translational Research, Wyeth, Collegeville, PA 19426. E-mail: hurkoo@wyeth.com. potential drug candidates is providing a challenge to development organizations that must really on laborintensive, increasingly expensive clinical trials to identify which of these candidates can become drugs, and ultimately products.

Drug development in humans has always provided special challenges because of inescapable practical, ethical, and regulatory constraints. This was true even when discovery organizations focused on incremental improvements -"me-too" drugs directed against targets whose relationship to human disease had already been established. Whereas preclinical validation is conducted in isogenic animals reared under identical conditions, development is conducted on outbred populations with equally heterogeneous lifestyles. Treatment in animal models commences at a precise interval after induction of an identical provocative lesion, whereas developmental testing occurs in naturally occurring disease of variable severity and duration. Treated animals can be sacrificed for examination of pathology and effects of treatment, using endpoints directly related to the induced pathology.

In contrast, ethical constraints require noninvasive measurements in humans. Drugs can only be registered if they demonstrate improvement in the less direct measures of clinical improvement and quality of life. The resulting variability requires sample sizes of hundreds or thousands of human subjects, rather than the dozens required for studies in animals. Costs are further in- 
creased by the regulatory requirements for tamper-proof locked databases. Instead of the multiple small iterative experiments typical in discovery laboratories, traditional development relies on relatively few meticulously preplanned large trials, with few opportunities for midcourse corrections informed by emerging data.

Nevertheless, the traditional paradigm of phase 1-4 studies was adequate to the task of developing the relative trickle of candidates that used to emerge from discovery laboratories, especially because the majority of the drug targets were well understood and development and regulatory strategies were well established. Although translational research may have been useful in this bygone era, it was hardly necessary. Even then, proposals were made to reshape the drug development paradigm into a "learn and confirm" paradigm, that encouraged more exploratory studies in early development, ${ }^{2}$ a harbinger of what we now refer to as translational research. Such a paradigm was not accepted then because of concerns that it would have resulted in unnecessary expense and delay to market. In the era of "me-too drugs" the likelihood of efficacy was relatively high. The paramount concern was speed to market. This is no longer the case given the risks inherent in not being certain that the target is relevant to human disease. In recent years, only 9\% of compounds that entered phase 1 survived to launch. Over $50 \%$ of this attrition resulted from failure to demonstrate efficacy in phase 2 studies, a $15 \%$ increase in phase 2 failures over the last decade. Compounds that worked beautifully on cloned human proteins and in animal models more often than not proved ineffective in human disease.

Experience demonstrated that behavior of a compound in an patient cannot be predicted perfectly from interactions with isolated human molecules or cells in vitro, nor from animal models.

Significant metabolic pathways in laboratory animals may be minor or redundant in humans. Animals models are not identical to human disease. In no other therapeutic area is that more true than for diseases of the CNS, demonstrably the organ system most uniquely distinguishing humans from laboratory animals. Indeed, only $3-5 \%$ of CNS candidates ever become marketed therapeutics. Waiting for demonstration of efficacy in a traditional phase 2 study is becoming an increasingly costly proposition. Further risk reduction is necessary before embarking on lengthy and expensive phase 2 trials using registrable endpoints on samples of the broadly defined populations that the target product profile aims for. Developing the tools for as well as execution of this risk reduction is the role of translational research.

In the largest sense, translational research could be taken to encompass the entire breadth of medicine: diagnosis, prognosis, and management. Such a definition is not helpful. For industrial translational research to be a practicable, nonduplicative addition to the current activities of integrated pharmaceutical companies, it is critical that the mission is focused sharply and its deliverables be defined clearly. There is no better way of defining the focus than by examining the root causes of failure in drug development in this era of novel, unproven targets. Drug candidates fail for one of four major reasons:

1) The compound is given to the wrong subjects.

2) The compound is given at the wrong dose or schedule.

3) The favorable effects of the compound are not detected.

4) The compound has a significant effect in laboratory species, but not in humans.

It is the mission of translational research to minimize the risk associated with the first three causes of failure and to permit efficient identification of the fourth, to ensure that the resources required for development and registration are allocated optimally.

\section{WHAT PATIENTS WILL RESPOND TO THE DRUG? PATIENT IDENTIFICATION/STRATIFICATION BIOMARKERS}

\section{Animal models are imperfect predictors of human efficacy}

Before a compound is judged suitable for testing in humans, it must first demonstrate safety and efficacy in animal models. The increasingly high failure rates of CNS compounds in human trials has demonstrated that this success in animals is no guarantee. No animal model is a perfect mimic of human disease. Animals can serve as models of disease mechanisms, but not of the disease itself. Arguably, nowhere is the disparity greater than for neuropsychiatric diseases. Failure rates in clinical development attest to the disparity.

Given our imperfect understanding of the pathophysiology of most neuropsychiatric diseases, the best guide is past experience with predecessor compounds that impact the same target or metabolic pathway. In psychiatric diseases, pharmacology has driven the science. The serendipitous observation that putative antimalarials calmed inmates of a psychiatric asylum let to the dopamine theory of schizophrenia and the serotonin theory of depression and anxiety. These theories remain the mainstay of the animal models used for preclinical validation. Although predictive for certain classes of compounds, such an approach is inherently circular and limiting. It is likely that there is more to the major psychoses than either direct or indirect failure of these two transmitter systems.

Even in diseases where there is a greater mechanistic understanding, there are still significant disparities between the animal models used in discovery validation and the human diseases being targeted for treatment. 
Transgenic models of Alzheimer disease show relatively little neurodegeneration, neuroinflammation, cognitive, or behavioral impairment. Multiple classes of compounds have proven effective in middle cerebral artery occlusion models of ischemic stroke, but almost all have failed in the clinic. Even in simple pain models, the discovery investigator can only observe the speed of withdrawal from painful stimuli, rather than pain itself.

The challenge of finding responsive human subjects is further compounded by the possibilities of disease heterogeneity. In all the aforementioned categories, we know that there are subtypes. Some of these may be pharmacologically relevant.

In the absence of previous pharmacological experience, how can translational research guide the choice of patients that may benefit from a novel putative therapeutic?

\section{GENETIC MUTATIONS IN HUMANS CAN HELP GUIDE CHOICE OF HUMAN SUBJECTS FOR DRUG DISCOVERY AND TRANSLATIONAL RESEARCH}

A potential substitute for a pharmacologic challenge to a putative drug target is a mutation that modifies its activity. ${ }^{3}$ Thus far, the greatest contribution of genetics to neurological drug discovery has been the support for the amyloid hypothesis of Alzheimer disease afforded by mutations of amyloid precursor protein or its metabolizing enzymes, presenilin 1 or 2 . These mutations are found in affected individuals in rare families segregating an early-onset disorder that is clinically and histologically similar to the sporadic old age disease that is the intended target of these therapies. Transgenic animal models are used widely for preclinical evaluation of putative disease-modifying therapies for treatment of sporadic Alzheimer disease. Certain features of the human disease are mimicked more closely than others. ${ }^{4,5}$ The strong association of apolipoprotein $\mathrm{E}$ with propensity to sporadic Alzheimer disease has not influenced drug discovery as strongly despite the availability of animal models. ${ }^{6,7}$ However, interest of the pharmaceutical industry in these models has increased belatedly with the independent epidemiological demonstration of the relationship of cholesterol metabolites and statin treatment on the incidence of sporadic Alzheimer disease. ${ }^{8,9}$

These genetic insights into Alzheimer disease have already been accepted widely by drug discovery organizations. There remains an opportunity for translational research to bring the many other findings of neurogenetics to the pharmaceutical industry. This impact that has been relatively modest to date, especially given the prominent contribution that neuropsychiatric diseases have played in human genetics. ${ }^{10}$

\section{Monogenic disorders}

There are two main reasons for this disparity. First is the rarity of the disorders for which simple Mendelian inheritance has allowed the ready identification of the causative mutation. A disproportionate number of diseases-about 200 neurologic diseases of the 500 in all categories for which the causative mutation has been identified by positional cloning-are neurological. ${ }^{11}$ However, most of these diseases are individually rare, and thus not attractive markets for the pharmaceutical industry. Nevertheless, just as in the case of the rare Mendelian cases of early-onset Alzheimer disease, both discovery and translational research of these rare but well characterized disorders will provide insight to a broader category of human diseases. For example, single-gene mutations causing cognitive impairment in multiple mental retardation disorders can provide a molecularly proven insight into the molecular mechanisms of human cognition. ${ }^{12}$

\section{Complex disorders}

The second reason for this disparity between the potential contribution from human genetics and its uptake by the pharmaceutical industry is that the psychiatric disorders that have provided most of the market for CNS drugs are heritable not as simple Mendelian traits, but in complex inheritance patterns. In the previous decade, the pharmaceutical industry spent millions of research dollars sponsoring association and linkage studies of common disorders, perhaps expecting a pay-off as rapid as that in genetic studies of single-gene Mendelian disorders. It was not that simple. The pay-offs are only now beginning to come in, and slowly at that. A combination of multiple genes and environmental influences contribute to susceptibility to schizophrenia, the depressive disorders, attention disorders, autism as well as some neurological disorders like multiple sclerosis. Just as was the case with apolipoprotein E, the lack of a clear cause and effect relationship hindered the development of animal models. More importantly, even though genetic associations have been demonstrated in these complex disorders, the genetic loci identified in genetic studies of complex disorders are too large to permit definitive identification of a specific gene, without corroborating biological evidence. ${ }^{13-15}$

\section{Schizophrenia}

Nevertheless, there have been some recent successes, several of them achieved by adding biological information from transcriptional profiling to standard genetic analyses. These combined approaches offer a more promising approach for translational research in pharmaceutical organizations than the more open-ended genehunting genetic studies of the previous decade. ${ }^{16,17} \mathrm{Com}$ parison of transcriptional profiles of prefrontal cortices harvested from schizophrenics and matched controls 
demonstrated a selective decrease of transcripts encoding proteins involved in presynaptic functioning, albeit variable among subjects. These findings were corroborated by in situ hybridization. The most consistently diminished transcripts were those for synapsin 2 and N-ethylmaleimide-sensitive factor, ${ }^{18}$ a protein involved in the recycling of vesicles. ${ }^{19}$ Further support for the role of synapsin 2 in schizophrenia came from both case control and transmission disequilibrium studies demonstrating association of synapsin 2 haplotypes with schizophrenia in population and family studies. ${ }^{20}$ Another transcriptional profiling analysis with a limited number of candidate schizophrenia genes demonstrated a 2.6-fold increase in expression of apoproteinL $1,{ }^{21}$ a high-density lipoprotein known to be encoded on chromosome 12q12, previously demonstrated to be a high-susceptibility locus for schizophrenia.

Promising leads have come from other approaches as well. Mutations of proline dehydrogenase contribute to susceptibility to schizophrenia in some individuals. ${ }^{22,23}$ Transmission disequilibrium analysis has demonstrated association of schizophrenia with the PPPeCC gene and the calcineurin $\gamma$ catalytic subunit. ${ }^{24}$ These findings are intriguing given the observation of Miakawa ${ }^{25}$ that mice with forebrain-specific conditional knockout of calcineurin had behavioral difficulties similar to those of schizophrenia. Variation in the epsin-4 gene, which encodes the clathrin-associated protein enthroprotin ${ }^{26}$ (with a role in the stability of synaptic vesicles) and is in linkage disequilibrium with a locus conferring susceptibility to schizophrenia. The finding of a translocation in a family with mental and behavioral disorder DISC1 (disrupted in schizophrenia 1$)^{27}$ were followed by linkage with chromosome in schizophrenics. ${ }^{28,29}$ Associations with schizophrenia have also been found with variants in nicotonic acetylcholine receptor 7 and diminution of prepulse inhibition ${ }^{30}$ as well as with variants in neuregulin $1 . .^{31,32}$

\section{Other psychiatric disorders}

Genetic studies of depression have identified multiple susceptibility loci, but many of these have proven difficult to reproduce. Of these, the most promising leads are polymorphisms in the FK binding protein 5 gene that plays a role in the stress hormone-regulating hypothalamic-pituitary-adrenal axis, associated with a faster response to drug treatment and increased recurrence of depressive episodes. ${ }^{33}$ Recently, a mutation in the tryptophan hydroxylase gene has been found in individuals with unipolar major depression. ${ }^{34}$ Similar promising leads have been found in attention deficit disorder. ${ }^{35}$

In summary, although the many pharmaceutical companies have been discouraged by the poor return on investment in their initial genetic studies of neuropsychiatric disorders, a small proportion of these studies have begun to yield specific information that may be directly applicable to drug discovery and to the identification of biomarkers identifying susceptible patients. Identification of mutations allows the production of transgenic mouse models and small interfering RNA knockdowns for preclinical validation by discovery biologists. Clinical and biological investigation of patients with these causative or predisposing mutations is likely to be a fertile area for translational research.

\section{Choice of patients/subjects: presymptomatic disease}

Development of disease-modifying therapy for neurodegenerative disorders is hampered by late diagnosis. Many neurodegenerative diseases cannot be diagnosed clinically until after substantial tissue loss has occurred. ${ }^{36-38}$ This provides a severe, possibly insurmountable, hurdle for novel disease modifying therapeutics. A useful endeavor for translational research is the development of reliable presymptomatic diagnosis that would allow institution of disease-modifying therapy prophylactically, before much tissue has been irretrievably lost.

Neuroimaging provides an opportunity to identify early signs of neuronal dysfunction in a characteristic pattern, before the development of significant irreversible tissue atrophy. This was first demonstrated using resting glucose positron emission tomography (PET) technology in asymptomatic individuals carrying pathogenic mutations in families segregating autosomal dominant early-onset Alzheimer disease. ${ }^{39}$ This finding was later extended to individuals at high risk for the development of typical late-onset sporadic Alzheimer disease by virtue of their apolipoprotein $\mathrm{E}$ status and an affected first-degree relative. ${ }^{40}$ These clinically healthy individuals demonstrated the same characteristic anatomical pattern of decreased glucose uptake as is seen in individuals with symptomatic Alzheimer disease, albeit with decreased severity, even though their age was up to two decades lower than the mean age of onset of dementia. Corroboration of this finding and searches for other methods of presymptomatic diagnosis by translational research would likely improve the chances of achieving efficacy with neuroprotective drugs.

\section{Choice of patients/subjects: challenge models}

Another approach to the translational goal of reducing patient heterogeneity in early clinical development of novel therapeutics is based not on the etiologic homogeneity discussed above, but on standardization of the timing and/or severity of the pathological insult that the drug candidate is intended to treat. Ethical considerations clearly preclude the induction of most pathologies in human beings, as is standard practice for animal validation experiments. However, for certain situations either naturally occurring or induced clinical models of disease do permit initial evaluation of novel therapeutics. 


\section{Challenge models for pain}

A mainstay in the evaluation of analgesics for the initial evaluation of analgesics for inflammatory pain is extraction of third molars. ${ }^{41}$ Volunteers are recruited from those individuals scheduled for such a procedure for therapeutic reasons. This model allows intervention at a precisely timed interval with respect to the lesion, typically after induction, but the model is also amenable to evaluation of prophylactic treatments. Other models create no lasting tissue damage and are sufficiently mild as to permit their induction in normal volunteers. Intradermal injection of capsaicin, ${ }^{42}$ with or without the additional application of noxious heat, provides a standardized pain stimulus for the initial evaluation of analgesics. Such a lesion provides the additional advantage of producing easily identified and measurable areas of primary and secondary hyperalgesia, each of which is subserved by different neurological mechanisms, pharmacologically distinct. This model can be extended further by the use of occlusion to selectively eliminate input from large myelinated fibers. It is in these mechanistic studies that the capsacin volunteer model offers the greatest advantage for the evaluation of compounds targeting as yet unproven pain targets. A recently introduced variant of such testing involves oral administration of capsaicin. ${ }^{43}$ Muscular pain can be modeled by injection of hypertonic saline. ${ }^{44}$ Volunteer studies such as these can be extended by application of painful electrical stimuli. ${ }^{45}$ The delivery of these stimuli can be graded not only in severity but also in frequency, providing quantifiable measurements of temporal summation and wind-up, important indicators of central sensitization, an important component of chronic neuropathic pain. ${ }^{64}$

\section{Stroke model in humans}

Another potential model system is available for the study of stroke in humans. This is provided by the use of heart-lung bypass procedures necessary to support patients during certain types of cardiac surgery, such as coronary artery bypass. Depending on the center and the type of procedure, there is a $2-5 \%$ incidence of ischemic stroke in the first few hours of the procedure and recovery. An even higher risk group can be identified preoperatively by simple clinical criteria. ${ }^{46}$ In this group, magnetic resonance imaging (MRI) scanning demonstrates a higher incidence of stroke than observed clinically. ${ }^{47}$ Translational studies of neuroprotective compounds with this high risk group are likely to provide a useful method of risk reduction for putative neuroprotective drugs. Although very many compounds have proven effective in animal models of stroke, almost none have been successful clinically. In large part, the disparity between animal and human results can be attributed to an exquisite time dependence of such therapy. In traditional human stroke trials, patients are binned in large intervals-typically 3 or $6 \mathrm{~h}$ after the onset of stroke symptoms-to achieve enrollment goals. This introduces a great deal of variance in the results, a variance that is difficult to calculate precisely. Animal studies have uniformly shown that the earlier therapy begins, the more effective the treatment. Even a few minutes have a significant effect. Ideally, the drug is on board before the vessel is occluded.

The predictable high incidence of stroke in a narrowly defined temporal window in heart-lung bypass patients permits testing of neuroprotective agents either prophylactically or at a carefully predetermined interval after the injury. Translational studies using this model would test novel neuroprotectants in an ideal setting to judge the efficacy of neuroprotective compound in humans. Only those compounds that prove effective in this model would be advanced to standard phase 2 trials.

\section{Models of anxiety and panic}

Other provocative models have been adopted for initial testing of CNS drugs. Anxiolytics can be tested in normal volunteers asked to perform public speaking ${ }^{48,49}$; or in those individuals anxious in anticipation of a scheduled dental extraction. ${ }^{50,51}$ Other provocative tests for the induction of anxiety in normal volunteers include inhalation of carbon dioxide, ${ }^{52,53}$ infusion of lactic acid, ${ }^{54}$ or cholecystokinin. ${ }^{55-57}$ Of these various pharmacologically inducing anxiety models, cholecystokinin infusion is thought to most closely mimic the physiologic changes associated with generalized anxiety disorder, its attendant changes in the stress-hypothalamic pituitary axis, and consequently for its predictive value of therapeutic effect of a wide variety of anxiolytics in the less easily studied spontaneous anxiety disorders. ${ }^{58,59}$

\section{Model of cognitive impairment in Alzheimer disease}

Less widely used challenge models include scopolamine-induced cognitive impairment, which mimics some of the cognitive impairments associated with Alzheimer disease. ${ }^{60,61}$ Scopolamine challenge has been applied both in animal models ${ }^{62}$ as well as in normal human volunteers. However, the cognitive deficits produced by scopolamine differ in substantial respects from that seen in Alzheimer disease. ${ }^{63}$ Although the scopolamine model has been used with some success in the human validation of antichlolinesterase drugs, its predictive value for putative cognitive enhancers working by other mechanisms has yet to be established.

\section{Model of positive symptoms of schizophrenia}

Challenge with several different pharmacologic compounds that induce psychosis or delirium in normal human volunteers have been used to model the positive symptoms of schizophrenia, with varying degrees of success. $^{64}$ Of these the most widely used is ketamine. ${ }^{65,66}$ Ketamine has also been used to model schizophrenia in rats, permitting similar evaluations of putative antipsy- 
chotic drugs preclinically and clinically. ${ }^{67}$ However, the predictive value of either human or rodent challenge models for antipsychotic drugs working through nondopaminergic mechanisms have yet to be established.

\section{2) IS THE DRUG INTERACTING APPROPRIATELY WITH THE TARGET? PHARMACODYNAMIC BIOMARKERS}

Central to the success of any drug development project is ensuring that the drug reaches its target with the appropriate degree of saturation and for the appropriate duration. Because of fixed dosing as well as pharmacokinetic variation between human subjects, direct measurements of receptor occupancy are desirable. This is true in all therapeutic areas. However, development of CNS drugs poses the additional twin challenges of the blood brain barrier (impenetrable to the majority of $\operatorname{drugs}^{68}$ ) and the inaccessibility of brain targets to direct measurements in vivo. ${ }^{69}$ A useful undertaking for translational research for the development of CNS drugs is the development and execution of estimates of drug-receptor occupancy.

\section{Receptor occupancy by ligand PET}

Of these, the most direct is the use of $\mathrm{PET}^{70}$ scanning using site-specific ligands radiolabeled to high specific activity with positron emitting isotopes-usually carbon 11 or fluorine 18. The high specific activity of such labels has the advantage that even miniscule, subpharmacologic doses of such ligands can register a signal detectable by a PET camera, providing a quantifiable three-dimensional image of receptor occupancy in the brain. The receptor occupancy required of the radioligand is so low that there is no physiological perturbation of the system. Radioligand PET can be used to estimate receptor occupancy of an unlabeled drug of interest, administered at pharmacologic doses, by measuring displacement of the radiolabeled tracer. Although expensive and laborious, when a suitable PET tracer is available, this is the procedure of choice for the estimation of drug receptor occupancy in the otherwise inaccessible CNS. Currently, there exist suitable PET radioligands for only a few dozen receptors, ${ }^{71}$ limiting the generalizability of this procedure. Of the PET ligands currently available for displacement studies, the most widely used include: raclopride, for assessment of D2 dopamine receptor occupancy $^{72}$; WAY 100635, for detecting occupancy at the serotonin $1 \mathrm{~A}$ receptor ${ }^{71}$; and risperidone for $5 \mathrm{HT} 2 \mathrm{~A}$ receptors. $^{73}$

The utility of direct measurements of receptor occupancy by PET radioligand displacement is demonstrated by the example of F18 SPA-RQ, which labels the neurokinin 1 receptor, in the development of the centrally active antiemetic compound aprepitant. ${ }^{74-76}$ Demonstra- tion of complete occupancy of the central NK1 receptor with an intermediate dosing regimen provided a ceiling above which no further dose escalations were warranted. This accomplished two purposes. It set the maximal dose for use of this compound as an antiemetic for which partial efficacy was demonstrated at the intermediate dose. Furthermore, it blocked further dose escalation in search of a hypothesized antidepressant effect, antidepressant efficacy being absent even when the NK1 receptors were fully occupied by the drug.

For other compounds, other values of drug occupancy may be informative, although clearly not as definitive as in the example given above. As a general rule, for receptor antagonists, which represent the largest proportion of drugs targeting seven transmembrane G protein-coupled receptors, efficacy is achieved only when the majority of receptor sites are occupied by drug. In contrast, the less frequent agonist drugs need only achieve a few percent occupancy to be effective. Further guidance to receptor occupancy may be provided by determining receptor occupancy in the effective dose range of an appropriate animal model.

When no suitable PET ligand is developed, this provides an opportunity for translational research. The development and validation of a novel PET ligand requires several years of effort by a team of specialized chemists, biologists, and additional personnel.

\section{CSF sampling}

Some investigators propose a less exact approximation based on sampling of CSF. ${ }^{77,78}$ Although this method is safe, tolerable, and less expensive than radioligand PET displacement, it does not offer a direct estimate of receptor occupancy, the critical variable for drug action.

\section{Other pharmacodynamic biomarkers}

A third approach to the estimation of drug-target interactions in the CNS is through the use of other pharmacodynamic biomarkers: measurable downstream consequences of drug-target interactions that may have nothing to do with the intended consequences of the drug but may represent activation of a parallel pathway. Well recognized examples are uses of pupillometry to measure activation of central autonomic pathways ${ }^{79}$; measurement of anterior and posterior pituitary peptides to assess perturbation of the hypothalamic pituitary axis ${ }^{80}$; and assessment of other autonomic responses. ${ }^{81}$ An electrophysiological measure known as the bispectral index and related electrophysiological measures have been used widely in clinical settings to judge the depth of anesthesia. ${ }^{82,83}$ The utility of these measures as more general pharmacodynamic measures have yet to be explored fully. 


\section{3) IS THE DRUG WORKING? EFFICACY BIOMARKERS}

In this era of novel drug targets, it may happen that the first two translational questions were satisfied-the optimal human subjects were selected for dosing and the dosing regimen provided optimal receptor occupancy by the drug - and yet the drug has no positive therapeutic effect. What may have been a significant metabolic or physiological pathway in an animal model may not be so in a human disease. Indeed, phase 2 proof-of-concept studies are currently the major source of failure for CNS drugs, as well as others. Phase 2 registration studies demonstrate efficacy using clinical endpoints, which are often indirect and noisy. This in turn requires large sample sizes and prolonged observation. In contrast, translational studies using efficacy biomarkers and more highly selected test populations could provide a test of efficacy with smaller test groups and shorter observation periods. Only those compounds that demonstrate efficacy in such idealized translational studies, would progress to phase 2 registration studies. The potential utility of efficacy biomarkers is greatest for chronic disorders for which there is a long delay before clinical improvement can be observed reliably even though the initial beneficial effects on the disease pathophysiology may have commenced early in the course of drug treatment.

\section{Most efficacy biomarkers are not surrogates}

Efficacy biomarkers may, at the discretion of the company, be used for internal decision making even if they have not received the full degree of validation that would be required for the status of surrogates. ${ }^{84-86}$ A surrogate biomarker is one that tracks so closely with the clinical outcome that it may substitute for that clinical outcome as a primary endpoint in a registration study. ${ }^{88,89}$ To be acceptable as a surrogate, the biomarker must demonstrate that the behavior of the marker with respect to clinical outcome is not an accidental association ${ }^{90}$ as had been the case in agents that increased radiographic bone density but did not protect against osteoporotic fractures. ${ }^{91}$ Part of that requirement is validation by more than one drug. Current surrogates are few: hypertension, cholesterol, and HIV viral titer, among them. Less validated efficacy biomarkers cannot be used as primary endpoints in registration studies. They can, however be used for risk reduction in translational studies, saving development resources for those compounds that have demonstrated some potentially useful activity in man.

\section{Imaging efficacy biomarker for multiple sclerosis}

Several widely accepted efficacy biomarkers that have not yet achieved the validation required for surrogate status involve neuroimaging. The seminal example is the use of contrast MRI to demonstrate the periodic appearance of new inflammatory demyelinating lesions during the course of relapsing-remitting multiple sclerosis, many of them clinically silent. ${ }^{92-94}$ A number of putative treatments, initially the interferons, were able to demonstrate convincingly a reduction in the appearance of such new enhancing MRI lesions during controlled clinical trials. This was only a secondary endpoint in registration studies, but it gave a strong signal, bolstering the claim of efficacy supported by a much weaker signal from the primary endpoint of clinical disability score..$^{95,96}$ This success lifted multiple sclerosis from the ranks of those diseases judged intractable by the pharmaceutical industry, to an active area of both commercial as well as academic activity.

\section{Volumetric imaging biomarkers for stroke and Alzheimer disease}

Indeed, volumetric MRI measurements are likely to be more sensitive than clinical outcome measures in other multifocal brain disorders, because of the unique juxtaposition of eloquent and clinically silent regions in the human brain. Reduction in stroke volume is acceptable to many investigators as a measure of efficacy of neuroprotectants or thrombolytics in treatment trials for ischemic stroke, even though there is as yet insufficient validation for its use as a surrogate. The recently initiated Alzheimer Disease Neuroimaging Initiative (ADNI) is systematically investigating the relationship of brain atrophy to clinical outcome in Alzheimer disease. If successful, this study may lead to the adoption of assessments of global or regional brain volume by MRI as an efficacy biomarkers for disease modifying treatment of Alzheimer disease. ${ }^{97-100}$

\section{Imaging amyloid}

Other imaging methods merit investigation as potential efficacy biomarkers for disease modification in Alzheimer disease. For those therapies that aim to ameliorate brain amyloid levels, quantification of brain amyloid burden by PET imaging may prove an early efficacy biomarker. ${ }^{101-104}$ It seems likely that compounds working through this mechanism may favorably alter amyloid burden before cognitive improvement occurs or atrophy is halted. If so, translational studies using reduction of amyloid burden as an endpoint may be useful addition to an early development program. Other potentially useful efficacy biomarkers may come from resting ${ }^{105,106}$ or functional glucose uptake PET studies. ${ }^{107}$

\section{CSF biomarkers for Alzheimer disease}

The use of soluble biomarkers as efficacy measures of disease-modifying treatment of Alzheimer disease and other neurodegenerative disease has lagged behind the development of neuroimaging biomarkers. ${ }^{108}$ Much of the work on soluble biomarkers in Alzheimer disease has been focused on the CSF, which is not only more proximal to the CNS than blood, but also has a simpler 
composition, facilitating analysis. ${ }^{109,110}$ The relationship between CSF amyloid and clinical stage is not straightforward, following an inverted U-shaped distribution. The relationship of tau appears monotonic: steadily rising, ${ }^{111}$ as does the relationship for byproducts of oxidative stress. ${ }^{112}$ The search for other biochemical parameters that may track with disease progression have extended to proteomic analyses of cerebrospinal fluid $^{113,114}$ and brain parenchyma ${ }^{115,116}$ of patients with Alzheimer disease.

\section{Proteomic biomarkers for Parkinson disease}

Similar proteomic searches for potential efficacy biomarkers have been undertaken for another progressive neurodegenerative disorder, Parkinson disease. ${ }^{117-119}$ These initial searches for potential efficacy biomarkers are at an earlier stage than are those for Alzheimer disease. Analysis thus far has been limited to the CNS parenchyma in autopsy specimens, inaccessible in life as a clinical biomarker, but a potential source of protein that could be released into the CSF.

\section{Proteomic biomarkers for schizophrenia}

Proteomic analytic searches for potential efficacy biomarkers have been extended even to nonprogressive encephalopathies such as schizophrenia. Analysis of CSF in schizophrenics has demonstrated significant increases in levels of apolipoprotein A-IV, as well as other proteins. ${ }^{120}$ It is not yet known how these alterations track with disease activity and, thus, whether they would be useful as suitable efficacy biomarkers. Proteomic analyses of brain tissue from schizophrenic brains may identify products that are released into the CSF. ${ }^{121,122}$ Of the studies completed to date, the most promising appears to be a combined proteomic and metabolomic analysis that has provided evidence of oxidative damage, ${ }^{123}$ a finding interesting not only as source of efficacy biomarkers, but in the potential understanding of a basic disease mechanism. Corroboration or refutal of such findings is a high priority for translational research.

\section{Proteomic and transcriptional biomarkers for pain}

For certain CNS therapeutic areas, notably analgesics for either neuropathic or inflammatory pain, there is little need for molecular efficacy biomarkers to aid drug development. Efficacy can be most conveniently monitored by standard clinical endpoints such as patient report of symptoms. Nevertheless, translational studies may prove useful in elucidation of mechanism. Proteomic and transcriptional analyses of pain models have thus far been limited to preclinical species. ${ }^{124-130}$

\section{Physiological biomarkers for schizophrenia}

Long known electrophysiologic abnormalities offer potential efficacy biomarkers for schizophrenia, contrary to prior expectations. Characteristic abnormalities of pre- pulse inhibition, ${ }^{131}$ auditory gating, ${ }^{132}$ delay and/or diminution of amplitude of other evoked potentials have long been recognized characteristics of schizophrenia, as have been abnormalities of saccadic eye movements. ${ }^{133}$ However, these abnormalities have also been observed in nonpsychotic first-degree relatives and were not altered with antipsychotic treatment of symptomatic schizophrenics. ${ }^{134}$ For these reasons, they have been considered endophenotypic, trait biomarkers rather than markers of disease severity. As such, they not been used as efficacy biomarkers in the development of antischizophrenic drugs, most of which target positive symptoms only. However, recent findings indicate they may be worth revisiting as potential biomarkers for the development of drugs designed to ameliorate the equally problematic negative symptoms and cognitive impairment in schizophrenia, present in first-degree relatives and not significantly ameliorated, if at all, by antipsychotic medications. ${ }^{135,136}$

\section{CONCLUSION}

In this challenging time for the pharmaceutical industry, translational research offers an opportunity to bridge the gap between discovery in animals and development in humans. Nowhere are the challenges or potential rewards greater than in the discovery and development of drugs for the CNS. Although formal translational research efforts in fully integrated pharmaceutical companies are rather new, enough of technical and scientific background in the understanding of human disease has already been established that many of the tools necessary for implementation are already in place. Much of this work has already been accomplished in academic, government-sponsored as well as industrial laboratories. Continued collaboration between these institutions will facilitate translation of advances made at the bench to therapies for neurological and psychiatric diseases, many of them previously thought intractable.

What is needed from translational scientists is careful selection and prioritization from these myriad of data and technical advances, only those refinements that best serve the early developmental needs of the discovery portfolio in a timely manner. Whatever the risks, the industry will not tolerate delay. A few clear successes will far surpass the impact of a more diffuse effort. This is best accomplished by close collaboration of preclinical counterparts as well as the developmental clinicians and scientists who will ultimately perform the registration studies that will bring drugs to registration and to market.

The application and interpretation of the output of the new technologies of proteomics, transcriptional profiling, metabolomics, and neuroimaging falls directly into the purview of translational research. As was predicted nearly 10 years ago, ${ }^{2}$ the "learn" phase of development is 
becoming more and more critical for the success rate of phase 2 studies and the eventual registration of new drugs. Translational research has become a key factor in the production of new innovative therapies.

\section{REFERENCES}

1. Drews J. In quest of tomorrow's medicines. New York: Springer, 1998.

2. Sheiner L. Learning versus confirming in clinical drug development. Clin Pharm Ther 61:275-291, 1997.

3. Schadt EE, Monks SA, Friend SH. A new paradigm for drug discovery: integrating clinical genetic, genomic and molecular phenotype data to identify drug targets. Biochem Soc Trans 31: 437-443, 2003.

4. Hsiao K, Chapman P, Nilsen S, Eckman C, Harigaya Y, Younkin S, Yang F, Cole G. Correlative memory deficits, A- $\beta$ elevation, and amyloid plaques in transgenic mice. Science 274:99-103, 1996.

5. Citron M, Westaway D, Xia W, Carlson G, Diehl T, Levesque G, Johnson-Wood K, Lee M, Seubert P, Davis A, Kholodenko D, Motter R, Sherrington R, Perry B, Yao H, Strome R, Lieberburg I, Rommens J, Kim S, Schenk D, Fraser P, St. George Hyslop P, Selkoe DJ. Mutant presenilins of Alzheimer's disease increase production of 42-residue amyloid $\beta$-protein in both transfected cells and transgenic mice. Nat Med 3:67-72, 1997.

6. Saunders AM, Strittmatter WJ, Schmechel D, St. George-Hyslop PH, Pericak-Vance MA, Joo SH, Rosi BL, Gusella JF, CrapperMacLachlan DR, Alberts M, Hulette C, Crain B, Goldgaber D, Roses AD. Association of apolipoprotein E allele E4 with lateonset familial and sporadic Alzheimer's disease. Neurology 43: 1467-1472, 1993.

7. Harris FM, Brecht WJ, Xu Q, Tesseur I, Kekonius L, Wyss-Coray T, Fish JD, Masliah E, Hopkins PC, Scearce-Levie K, Weisgraber KH, Mucke L, Mahley RW, Huang Y. Carboxyl-terminal-truncated apolipoprotein E4 causes Alzheimer's disease-like neurodegeneration and behavioral deficits in transgenic mice. Proc Nat Acad Sci USA 100:10966-10971, 2003.

8. Evans RM, Hui S, Perkins A, Lahiri DK, Poirier J, Farlow MR. Cholesterol and APOE genotype interact to influence Alzheimer disease progression. Neurology 62:1869-1871, 2004.

9. Dufouil C, Richard F, Fievet N, Dartigues JF, Ritchie K, Tzourio C, Amouyel P, Alperovitch A. APOE genotype, cholesterol level, lipid-lowering treatment, and dementia: the Three-City Study. Neurology 64:1531-1538, 2005.

10. Hurko O. Genetics and genomics in neuropsychopharmacology: the impact on drug discovery and development. Eur Neuropsychopharmacol 11:491-499, 2001.

11. Hurko O. The explosion of neurogenetics. Curr Opin Neurol 10:77-83, 1997.

12. Weeber EJ, Levenson JM, Sweatt JD. Molecular genetics of human cognition. Mol Interv 2:376-391, 2002.

13. Terwilliger JD, Weiss KM. Confounding, ascertainment bias, and the blind quest for a genetic 'fountain of youth.' Ann Med 35: 532-554, 2003.

14. Terwilliger JD, Weiss KM. Linkage disequilibrium mapping of complex disease: fantasy or reality? Curr Opin Biotechnol 9:578-594, 1998.

15. Terwilliger JD, Goring HH. Gene mapping in the 20th and 21st centuries: statistical methods, data analysis, and experimental design. Hum Biol 72:63-132, 2000.

16. Schadt EE, Monks SA, Friend SH. A new paradigm for drug discovery: integrating clinical genetic, genomic and molecular phenotype data to identify drug targets. Biochem Soc Trans 31: 437-443, 2003.

17. Lesko LJ, Woodcock J. Pharmacogenomic-guided drug development: regulatory perspective. Pharmacogenom J 2:20-24, 2002.

18. Mirnics K, Middleton FA, Marquez A, Lewis DA, Levitt P. Molecular characterization of schizophrenia viewed by microarray analysis of gene expression in prefrontal cortex. Neuron 28 : 53-67, 2000.
19. Hoyle J, Phelan JP, Bermingham N, Fisher EMC. Localization of human and mouse N-ethylmaleimide-sensitive factor (NSF) gene: a two-domain member of the AAA family that is involved in membrane fusion. Mamm Genome 7:850-852, 1996.

20. Chen Q, He G, Wang XY, Chen QY, Liu XM, Gu ZZ, Liu J, Li KQ, Wang SJ, Zhu SM, Feng GY, He L. Positive association between synapsin II and schizophrenia. Biol Psychiatry 56:177181, 2004.

21. Mimmack ML, Ryan M, Baba H, Navarro-Ruiz J, Iritani S, Faull RLM, McKenna PJ, Jones PB, Arai H, Starkey M, Emson PC, Bahn S. Gene expression analysis in schizophrenia: reproducible up-regulation of several members of the apolipoprotein L family located in a high-susceptibility locus for schizophrenia on chromosome 22. Proc Nat Acad Sci USA 99:4680-4685, 2002.

22. Jacquet H, Raux G, Thibaut F, Hecketsweiler B, Houy E, Demilly C, Haouzir S, Allio G, Fouldrin G, Drouin V, Bou J, Petit P, Campion D, Frebourg T. PRODH mutations and hyperprolinemia in a subset of schizophrenic patients. Hum Mol Genet 11:2243$2249,2002$.

23. Liu H, Heath SC, Sobin C, Roos JL, Galke BL, Blundell ML, Lenane M, Robertson B, Wijsman EM, Rapoport JL, Gogos JA, Karayiorgou M. Genetic variation at the 22q11 PRODH2/ DGCR6 locus presents an unusual pattern and increases susceptibility to schizophrenia. Proc Nat Acad Sci USA 99:3717-3722, 2002.

24. Gerber DJ, Hall D, Miyakawa T, Demars S, Gogos JA, Karayiorgou M, Tonegawa S. Evidence for association of schizophrenia with genetic variation in the 8p21.3 gene, PPP3CC, encoding the calcineurin $\gamma$ subunit. Proc Nat Acad Sci 100:8993-8998, 2003.

25. Miyakawa T, Leiter LM, Gerber DJ, Gainetdinov RR, Sotnikova TD, Zeng H, Caron MG, Tonegawa S. Conditional calcineurin knockout mice exhibit multiple abnormal behaviors related to schizophrenia. Proc Natl Acad Sci 100:8987-8992, 2003.

26. Pimm J, McQuillin A, Thirumalai S, Lawrence J, Quested D, Bass N, Lamb G, Moorey H, Datta SR, Kalsi G, Badacsonyi A, Kelly K, Morgan J, Punukollu B, Curtis D, Gurling H. The epsin 4 gene on chromosome $5 \mathrm{q}$, which encodes the clathrin-associated protein enthoprotin, is involved in the genetic susceptibility to schizophrenia. Am J Hum Genet 76:902-907, 2005.

27. St. Clair D, Blackwood D, Muir W, Carothers A, Walker M, Spowart G, Gosden C, Evans HJ. Association within a family of a balanced autosomal translocation with major mental illness. Lancet 336:13-16, 1990.

28. Ekelund J, Hovatta I, Parker A, Paunio T, Varilo T, Martin R, Suhonen J, Ellonen P, Chan G, Sinsheimer JS, Sobel E, Juvonen H, Arajarvi R, Partonen T, Suvisaari J, Lonnqvist J, Meyer J, Peltonen L. Chromosome 1 loci in Finnish schizophrenia families. Hum Mol Genet 10:1611-1617, 2001.

29. Hennah W, Varilo T, Kestila M, Paunio T, Arajarvi R, Haukka J, Parker A, Martin R, Levitzky S, Partonen T, Meyer J, Lonnqvist J, Peltonen L, Ekelund J. Haplotype transmission analysis provides evidence of association for DISC1 to schizophrenia and suggests sex-dependent effects. Hum Mol Genet 12:3151-3159, 2003.

30. Freedman R, Coon H, Myles-Worsley M, Orr-Urtreger A, Olincy A, Davis A, Polymeropoulos M, Holik J, Hopkins J, Hoff M, Rosenthal J, Waldo MC, et al. Linkage of a neurophysiological deficit in schizophrenia to a chromosome 15 locus. Proc Nat Acad Sci USA 94:587-592, 1997.

31. Stefansson H, Sarginson J, Kong A, Yates P, Steinthorsdottir V, Gudfinnsson E, Gunnarsdottir S, Walker N, Petursson H, Crombie C, Ingason A, Gulcher JR, Stefansson K, St. Clair D. Association of neuregulin 1 with schizophrenia confirmed in a Scottish population. Am J Hum Genet 72:83-87, 2003.

32. Li T, Stefansson H, Gudfinnsson E, Cai G, Liu X, Murray RM, Steinthorsdottir V, Januel D, Gudnadottir VG, Petursson H, Ingason A, Gulcher JR, Stefansson K, Collier DA. Identification of a novel neuregulin 1 at-risk haplotype in Han schizophrenia Chinese patients, but no association with the Icelandic/Scottish risk haplotype. Mol Psychiatry 9:698-704, 2004.

33. Binder EB, Salyakina D, Lichtner P, Wochnik GM, Ising M, Putz B, Papiol S, Seaman S, Lucae S, Kohli MA, Nickel T, Kunzel HE, et al. Polymorphisms in FKBP5 are associated with increased 
recurrence of depressive episodes and rapid response to antidepressant treatment. Nat Genet 36:1319-1325, 2004.

34. Zhang X, Gainetdinov RR, Beaulieu J-M, Sotnikova TD, Burch LH, Williams RB, Schwartz DA, Krishnan KRR, Caron MG. Loss-of-function mutation in tryptophan hydroxylase-2 identified in unipolar major depression. Neuron 45:11-16, 2005.

35. Kustanovich V, Ishii J, Crawford L, Yang M, McGough JJ, McCracken JT, Smalle SL, Nelson SF. Transmission disequilibrium testing of dopamine-related candidate gene polymorphisms in ADHD: confirmation of association of ADHD with DRD4 and DRD5. Mol Psychiatry 9:711-717, 2004.

36. Fleisher A, Grundman M, Jack CR Jr, Petersen RC, Taylor C, Kim HT, Schiller DH, Bagwell V, Sencakova D, Weiner MF, DeCarli C, DeKosky ST, van Dyck CH, Thal LJ. Alzheimer's Disease Cooperative Study. Sex, apolipoprotein E epsilon 4 status, and hippocampal volume in mild cognitive impairment. Arch Neurol 62:953-957, 2005.

37. Brucke T, Djamshidian S, Bencsits G, Pirker W, Asenbaum S, Podreka I. SPECT and PET imaging of the dopaminergic system in Parkinson's disease. J Neurol 247 [Suppl 4]:IV/2-7, 2000.

38. Kalra S, Arnold D. Neuroimaging in amyotrophic lateral sclerosis. Amyotroph Lateral Scler Other Motor Neuron Disord 4:243248, 2003.

39. Kennedy AM, Frackowiak RS, Newman SK, Bloomfield PM, Seaward J, Roques P, Lewington G, Cunningham VJ, Rossor MN. Deficits in cerebral glucose metabolism demonstrated by positron emission tomography in individuals at risk of familial Alzheimer's disease. Neurosci Lett 186:17-20, 1995.

40. Reiman EM, Caselli RJ, Yun LS, Chen K, Bandy D, Minoshima S, Thibodeau SN, Osborne D. Preclinical evidence of Alzheimer's disease in persons homozygous for the epsilon 4 allele for apolipoprotein E. N Engl J Med 334:752-758, 1996.

41. Moller PL, Juhl GI, Payen-Champenois C, Skoglund LA. Intravenous acetaminophen (paracetamol): comparable analgesic efficacy, but better local safety than its prodrug, propacetamol, for postoperative pain after third molar surgery. Anesth Analg 101: 90-96, 2005.

42. McBurney DH, Balaban CD, Popp JR, Rosenkranz JE. Adaptation to capsaicin burn: effects of concentration and individual differences. Physiol Behav 72:205-216, 2001.

43. Balaban CD, McBurney DH, Affeltranger MA. Three distinct categories of time course of pain produced by oral capsaicin. $J$ Pain 6:315-322, 2005.

44. Farina D, Arendt-Nielsen L, Graven-Nielsen T. Experimental muscle pain decreases voluntary EMG activity but does not affect the muscle potential evoked by transcutaneous electrical stimulation. Clin Neurophysiol 116:1558-1565, 2005.

45. Enggaard TP, Klitgaard NA, Sindrup SH. Specific effect of levetiracetam in experimental human pain models. Eur J Pain, 6 June 2005.

46. McKhann GM, Goldsborough MA, Borowicz LM Jr, Mellits ED, Brookmeyer R, Quaskey SA, Baumgartner WA, Cameron DE, Stuart RS, Gardner TJ. Predictors of stroke risk in coronary artery bypass patients. Ann Thorac Surg 63:516-521, 1997.

47. Restrepo L, Wityk RJ, Grega MA, Borowicz L Jr, Barker PB, Jacobs MA, Beauchamp NJ, Hillis AE, McKhann GM. Diffusionand perfusion-weighted magnetic resonance imaging of the brain before and after coronary artery bypass grafting surgery. Stroke 33:2909-2915, 2002.

48. Parente AC, Garcia-Leal C, Del-Ben CM, Guimaraes FS, Graeff FG. Subjective and neurovegetative changes in healthy volunteers and panic patients performing simulated public speaking. Eur Neuropsychopharmacol, 13 June 2005.

49. de-Paris F, Sant'Anna MK, Vianna MR, Barichello T, Busnello JV, Kapczinski F, Quevedo J, Izquierdo I. Effects of gabapentin on anxiety induced by simulated public speaking. $J$ Psychopharmacol 17:184-188, 2003.

50. Roelofse JA, Shipton EA, de la Harpe CJ, Blignaut RJ. Intranasal sufentanil/midazolam versus ketamine/midazolam for analgesia/ sedation in the pediatric population prior to undergoing multiple dental extractions under general anesthesia: a prospective, double-blind, randomized comparison. Anesth Prog 51:114-121, 2004.
51. Bell GW, Kelly PJ. A study of anxiety, and midazolam-induced amnesia in patients having lower third molar teeth extracted. $\mathrm{Br} \mathrm{J}$ Oral Maxillofac Surg 38:596-602, 2000.

52. Kent JM, Papp LA, Martinez JM, Browne ST, Coplan JD, et al. Specificity of panic response to $\mathrm{CO}(2)$ inhalation in panic disorder: a comparison with major depression and premenstrual dysphoric disorder. Am J Psychiatry 158:58-67, 2001.

53. Bourin M, Baker GB, Bradwejn J. Neurobiology of panic disorder. J Psychosom Res 44:163-180, 1998.

54. Klein DF. False suffocation alarms, spontaneous panics, and related conditions. An integrative hypothesis. Arch Gen Psychiatry 50:306-317, 1993.

55. Zwanzger P, Eser D, Aicher S, Schule C, Baghai TC, et al. Effects of alprazolam on cholecystokinin-tetrapeptideinduced panic and hypothalamic-pituitary-adrenal-axis activity: a placebo-controlled study. Neuropsychopharmacology 28:979-984, 2003.

56. Bradwejn J, Koszycki D, Annable L, Couetoux du Tertre A, Reines S, Karkanias C. A dose-ranging study of the behavioral and cardiovascular effects of CCK-tetrapeptide in panic disorder. Biol Psychiatry 32:903-912, 1992.

57. Kellner M, Yassouridis A, Hua Y, Wendrich M, Jahn H, Wiedemann K. Intravenous C-type natriuretic peptide augments behavioral and endocrine effects of cholecystokinin tetrapeptide in healthy men. J Psychiatr Res 36:16, 2002.

58. Bradwejn J, Koszycki D. Imipramine antagonism of the panicogenic effects of cholecystokinin tetrapeptide in panic disorder patients. Am J Psychiatry 151:261-263, 1994.

59. Zwanzger P, Baghai TC, Schuele C, Strohle A, Padberg F, et al. Vigabatrin decreases cholecystokinin-tetrapeptide (CCK-4) induced panic in healthy volunteers. Neuropsychopharmacology 25:699-703, 2001.

60. Wesnes K, Simpson P, Kidd A. An investigation of the range of cognitive impairments induced by scopolamine $0.6 \mathrm{mg}$ s.c. Hum Psychopharmacol 3:27-41, 1988.

61. Rabey JM, Neufeld MY, Treves TA, Sifris P, Korczyn AD. Cognitive effects of scopolamine in dementia. J Neural Transm 103:873-881, 1996.

62. Higgins GA, Enderlin M, Fimbel R, Haman M, Grottick AJ, Soriano M, Richards JG, Kemp JA, Gill R. Donepezil reverses a mnemonic deficit produced by scopolamine but not by perforant path lesion or transient cerebral ischaemia. Eur J Neurosci 15: 1827-1840, 2002.

63. Ebert U, Kirch W. Scopolamine model of dementia: electroencephalogram findings and cognitive performance. Eur J Clin Invest 28:944-999, 1998.

64. Lahti AC, Holcomb HH. Schizophrenia, VIII: pharmacologic models. Am J Psychiatry 160:2091, 2003.

65. Passie T, Karst M, Wiese B, Emrich HM, Schneider U. Effects of different subanesthetic doses of (s)-ketamine on neuropsychology, psychopathology, and state of consciousness in man. Neuropsychobiology 51:226-233, 2005.

66. Northoff G, Richter A, Bermpohl F, Grimm S, Martin E, Marcar VL, Wahl C, Hell D, Boeker H. NMDA hypofunction in the posterior cingulate as a model for schizophrenia: an exploratory ketamine administration study in fMRI. Schizophr Res 72:235248, 2005.

67. Becker A, Peters B, Schroeder H, Mann T, Huether G, Grecksch G. Ketamine-induced changes in rat behaviour: a possible animal model of schizophrenia. Prog Neuropsychopharmacol Biol Psychiatry 27:687-700, 2003.

68. Pardridge WM. Blood-brain barrier drug targeting: the future of brain drug development. Mol Interv 3:90-105, 2003.

69. Bieck PR, Potter WZ. Biomarkers in psychotropic drug development: integration of data across multiple domains. Anпи Rev Pharmacol Toxicol 45:227-246, 2005.

70. Ahmed S, Mozley PD, Potter WZ. Biomarkers in psychotropic drug development. Am J Geriatr Psychiatry 10:678-586, 2002.

71. http://www.snidd.org/

72. Kapur S, Zipursky R, Jones C, Remington G, Houle S. Relationship between dopamine $\mathrm{D}(2)$ occupancy, clinical response, and side effects: a double-blind PET study of first-episode schizophrenia. Am J Psychiatry 157:514-520, 2000. 
73. Nyberg S, Eriksson B, Oxenstierna G, Halldin C, Farde L. 1999 Suggested minimal effective dose of risperidone based on PETmeasured D2 and 5-HT2A receptor occupancy in schizophrenic patients. Am J Psychiatry 156:869-875, 1999.

74. Hargreaves R. Imaging substance P receptors (NK1) in the living human brain using positron emission tomography. J Clin Psychiatry 63 [Suppl 11]:18-24, 2002.

75. Bergstrom M, Hargreaves RJ, Burns DH, Goldberg MR, Sciberras D, et al. Human positron emission tomography studies of brain neurokinin 1 receptor occupancy by aprepitant. Biol Psychiatry 55:1007-1012, 2004.

76. Frank R, Hargreaves R. Clinical biomarkers in drug discovery and development. Nat Rev Drug Discov 2:566-580, 2003.

77. Nau R, Zysk G, Thiel A, Prange HW. Pharmacokinetic quantification of the exchange of drugs between blood and cerebrospinal fluid in man. Eur J Clin Pharmacol 45:469-475, 1993.

78. Zoli M, Jansson A, Sykova E, Agnati LF, Fuxe K. Volume transmission in the CNS and its relevance for neuropsychopharmacology. Trends Pharmacol Sci 20:142-150, 1999.

79. Fliegert F, Kurth B, Gohler K. The effects of tramadol on static and dynamic pupillometry in healthy subjects-the relationship between pharmacodynamics, pharmacokinetics and CYP2D6 metaboliser status. Eur J Clin Pharmacol 61:257-266, 2005.

80. Nikisch G, Mathe AA, Czernik A, Thiele J, Bohner J, Eap CB, Agren H, Baumann P. Long-term citalopram administration reduces responsiveness of HPA axis in patients with major depression: relationship with S-citalopram concentrations in plasma and cerebrospinal fluid (CSF) and clinical response. Psychopharmacology (Berl), 30 June 2005.

81. Vincent S, Bieck PR, Garland EM, Loghin C, Bymaster FP, et al. Clinical assessment of norepinephrine transporter blockade through biochemical and pharmacologic profile. Circulation 109: 320-327, 2004.

82. Fraser GL, Riker RR. Bispectral index monitoring in the intensive care unit provides more signal than noise. Pharmacotherapy 25 [5 Pt 2]:19S-27S, 2005.

83. Vanluchene AL, Vereecke H, Thas O, Mortier EP, Shafer SL, Struys MM. Spectral entropy as an electroencephalographic measure of anesthetic drug effect: a comparison with bispectral index and processed midlatency auditory evoked response. Anesthesiology 101:34-42, 2004.

84. Buyse M, Molenberghs G. Criteria for the validation of surrogate endpoints in randomized experiments. Biometrics 54:1014-1029, 1998.

85. De Gruttola VG, Clax P, DeMets DL, et al. Considerations in the evaluation of surrogate endpoints in clinical trials: summary of a National Institutes of Health workshop. Control Clin Trials 22: 485-502, 2001.

86. Rolan P, Atkinson A, Lesko LJ. Use of biomarkers from drug discovery through clinical practice: Report of the Ninth European Federation of Pharmaceutical Sciences Conference on optimizing drug development. Clin Pharm Ther 73:284-291, 2003.

87. Deleted in proof.

88. Temple R. Are surrogate markers adequate to assess cardiovascular disease drugs? JAMA 282:790-795, 1999.

89. Lonn E. The use of surrogate endpoints in clinical trials: focus on clinical trials in cardiovascular diseases. Pharmacoepidemiol Drug Saf 10:497-508, 2001.

90. Fleming TR, DeMets DL. Surrogate end points in clinical trials: are we being misled? [comment]. Ann Intern Med 125:605-613, 1996.

91. Keele MP, Voce GP. A study of bone density. Comparison of the effects of sodium fluoride, inorganic phosphate, and an anabolic sterois (oxymetholone) on demineralized bone. Am J Dis Child 118:759-764, 1969

92. Sormani MP, Bruzzi P, Comi G. Filippi M. MRI metrics as surrogate markers for clinical relapse rate in relapsing-remitting MS patients. Neurology 58:417-421, 2002.

93. McDonald WI, Compston A, Edan G, Goodkin D, Hartung HP, Lublin FD, McFarland HF, Paty DW, Polman CH, Reingold SC, Sandberg-Wollheim M, Sibley W, Thompson A, van den Noort S, Weinshenker BY, Wolinsky JS. Recommended diagnostic criteria for multiple sclerosis: guidelines from the International Panel on the diagnosis of multiple sclerosis. Ann Neurol 50:121-127, 2001.

94. Fazekas F, Barkhof F, Filippi M, Grossman RI, Li DK, McDonald WI, McFarland HF, Paty DW, Simon JH, Wolinsky JS, Miller DH. The contribution of magnetic resonance imaging to the diagnosis of multiple sclerosis. Neurology 53:448-456, 1999.

95. Paty DW. The interferon- $\beta 1 \mathrm{~b}$ clinical trial and its implications for other trials. Ann Neurol 36 [Suppl]:S113-S114, 1994.

96. Paty DW, Li DK. Interferon $\beta$-1b is effective in relapsing-remitting multiple sclerosis. II. MRI analysis results of a multicenter, randomized, double-blind, placebo-controlled trial. UBC MS/ MRI Study Group and the IFNB Multiple Sclerosis Study Group. Neurology 43:662-667, 1993.

97. Kantarci K, Jack CR Jr. Neuroimaging in Alzheimer disease: an evidence-based review. Neuroimaging Clin N Am 13:197-209, 2003.

98. Jack CR Jr, Slomkowski M, Gracon S, Hoover TM, Felmlee JP, Stewart K, Xu Y, Shiung M, O'Brien PC, Cha R, Knopman D, Petersen RC. MRI as a biomarker of disease progression in a therapeutic trial of milameline for AD. Neurology 60:253-260, 2003.

99. Jack CR Jr, Petersen RC, Xu Y, et al. Rates of hippocampal atrophy correlate with change in clinical status in aging and $\mathrm{AD}$. Neurology 55:484-489, 2000.

100. Mathis CA, Klunk WE, Price JC, DeKosky ST. Imaging technology for neurodegenerative diseases: progress toward detection of specific pathologies. Arch Neurol 62:196-200, 2005.

101. Klunk WE, Engler H, Nordberg A, Wang Y, Blomqvist G, Holt DP, Bergstrom M, Savitcheva I, Huang GF, Estrada S, Ausen B, Debnath ML, Barletta J, Price JC, Sandell J, Lopresti BJ, Wall A, Koivisto P, Antoni G, Mathis CA, Langstrom B. Imaging brain amyloid in Alzheimer's disease with Pittsburgh Compound-B. Ann Neurol 55:306-319, 2004.

102. Nordberg A PET imaging of amyloid in Alzheimer's disease. Lancet Neurol 3:519-527, 2004.

103. Mathis CA, Wang Y, Klunk WE. Imaging $\beta$-amyloid plaques and neurofibrillary tangles in the aging human brain. Curr Pharm Des 10:1469-1492, 2004.

104. Agdeppa ED, Kepe V, Liu J, Small GW, Huang SC, Petric A, Satyamurthy N, Barrio JR. 2-Dialkylamino-6-acylmalononitrile substituted naphthalenes (DDNP analogs): novel diagnostic and therapeutic tools in Alzheimer's disease. Mol Imaging Biol 5:404-417, 2003

105. Alexander GE, Chen K, Pietrini P, Rapoport SI, Reiman EM. Longitudinal PET evaluation of cerebral metabolic decline in dementia: a potential outcome measure in Alzheimer's disease treatment studies. Am J Psychiatry 159:738-745, 2002.

106. Silverman DH, Small GW, Chang CY, Lu CS, Kung De Aburto MA, Chen W, Czernin J, Rapoport SI, Pietrini P, Alexander GE, Schapiro MB, Jagust WJ, Hoffman JM, Welsh-Bohmer KA, Alavi A, Clark CM, Salmon E, de Leon MJ, Mielke R, Cummings JL, Kowell AP, Gambhir SS, Hoh CK, Phelps ME. Positron emission tomography in evaluation of dementia: regional brain metabolism and long-term outcome. JAMA 286:2120-2127, 2001.

107. Miller JD, de Leon MJ, Ferris SH, Kluger A, George AE, Reisberg B, Sachs HJ, Wolf AP. Abnormal temporal lobe response in Alzheimer's disease during cognitive processing as measured by 11C-2-deoxy-D-glucose and PET. J Cereb Blood Flow Metab 7:248-251, 1987

108. Galasko D. Biological markers and the treatment of Alzheimer's disease. J Mol Neurosci 17:119-125, 2001.

109. Yuan X, Russell T, Wood G, Desiderio DM. Analysis of the human lumbar cerebrospinal fluid proteome. Electrophoresis 23 : 1185-1196.

110. Terry DE, Desiderio DM. Between-gel reproducibility of the human cerebrospinal fluid proteome. Proteomics 3:1962-1979, 2003.

111. Galasko D, Chang L, Motter R, Clark CM, Kaye J, Knopman D, Thomas R, Kholodenko D, Schenk D, Lieberburg I, Miller B, Green R, Basherad R, Kertiles L, Boss MA, Seubert P. High cerebrospinal fluid tau and low amyloid $\beta 42$ levels in the clinical 
diagnosis of Alzheimer disease and relation to apolipoprotein E genotype. Arch Neurol 55:937-945, 1998.

112. Montine TJ, Montine KS, McMahan W, Markesbery WR, Quinn JF, Morrow JD. F2-isoprostanes in Alzheimer and other neurodegenerative diseases. Antioxid Redox Signal 7:269-275, 2005.

113. Zhang J, Goodlett DR, Quinn JF, Peskind E, Kaye JA, Zhou Y, Pan C, Yi E, Eng J, Wang Q, Aebersold RH, Montine TJ. Quantitative proteomics of cerebrospinal fluid from patients with Alzheimer disease. J Alzheimers Dis 7:125-133, 2005.

114. Puchades M, Hansson SF, Nilsson CL, Andreasen N, Blennow K, Davidsson P. Proteomic studies of potential cerebrospinal fluid protein markers for Alzheimer's disease. Brain Res Mol Brain Res 118:140-146, 2003.

115. Sultana R, Boyd-Kimball D, Poon HF, Cai J, Pierce WM, Klein JB, Markesbery WR, Zhou XZ, Lu KP, Butterfield DA. Oxidative modification and down-regulation of Pin1 in Alzheimer's disease hippocampus: 1 redox proteomics analysis. Neurobiol Aging, 9 June 2005.

116. Castegna A, Thongboonkerd V, Klein JB, Lynn B, Markesbery WR, Butterfield DA. Proteomic identification of nitrated proteins in Alzheimer's disease brain. J Neurochem 85:1394-1401, 2003.

117. Zhang J, Goodlett DR. Proteomic approach to studying Parkinson's disease. Mol Neurobiol 29:271-288, 2004.

118. Mandel S, Weinreb O, Youdim MB. Using cDNA microarray to assess Parkinson's disease models and the effects of neuroprotective drugs. Trends Pharmacol Sci 24:184-191, 2003.

119. Basso M, Giraudo S, Corpillo D, Bergamasco B, Lopiano L, Fasano M. Proteome analysis of human substantia nigra in Parkinson's disease. Proteomics 4:3943-3952, 2004.

120. Jiang L, Lindpaintner K, Li HF, Gu NF, Langen H, He L, Fountoulakis M. Proteomic analysis of the cerebrospinal fluid of patients with schizophrenia. Amino Acids 25:49-57, 2003.

121. Johnston-Wilson NL, Sims CD, Hofmann JP, Anderson L, Shore $\mathrm{AD}$, Torrey EF, Yolken RH. Disease-specific alterations in frontal cortex brain proteins in schizophrenia, bipolar disorder, and major depressive disorder. The Stanley Neuropathology Consortium. Mol Psychiatry 5:142-149, 2000.

122. Marcotte ER, Srivastava LK, Quirion R. cDNA microarray and proteomic approaches in the study of brain diseases: focus on schizophrenia and Alzheimer's disease. Pharmacol Ther 100: 63-74.

123. Prabakaran S, Swatton JE, Ryan MM, Huffaker SJ, Huang JT, Griffin JL, Wayland M, Freeman T, Dudbridge F, Lilley KS, Karp NA, Hester S, Tkachev D, Mimmack ML, Yolken RH, Webster MJ, Torrey EF, Bahn S. Mitochondrial dysfunction in schizophrenia: evidence for compromised brain metabolism and oxidative stress. Mol Psychiatry 9:684-697, 2004.

124. Tawfik VL, LaCroix-Fralish ML, Nutile-McMenemy N, DeLeo
JA. Transcriptional and translational regulation of glial activation by morphine in a rodent model of neuropathic pain. J Pharmacol Exp Ther 313:1239-1247, 2005.

125. Yu CG, Yezierski RP. Activation of the ERK1/2 signaling cascade by excitotoxic spinal cord injury. Brain Res Mol Brain Res, 9 June 2005.

126. Gineste C, Ho L, Pompl P, Bianchi M, Pasinetti GM. Highthroughput proteomics and protein biomarker discovery in an experimental model of inflammatory hyperalgesia: effects of nimesulide. Drugs 63 [Suppl 1]:23-29, 2003.

127. Alzate O, Hussain SR, Goettl VM, Tewari AK, Madiai F, Stephens RL Jr, Hackshaw KV. Proteomic identification of brainstem cytosolic proteins in a neuropathic pain model. Brain Res Mol Brain Res 128:193-200, 2004.

128. Sung HJ, Kim YS, Kim IS, Jang SW, Kim YR, Na DS, Han KH, Hwang BG, Park DS, Ko J. Proteomic analysis of differential protein expression in neuropathic pain and electroacupuncture treatment models. Proteomics 4:2805-2813, 2004.

129. Wang H, Sun H, Della Penna K, Benz RJ, Xu J, Gerhold DL, Holder DJ, Koblan KS. Chronic neuropathic pain is accompanied by global changes in gene expression and shares pathobiology with neurodegenerative diseases. Neuroscience 114:529-546, 2002.

130. Valder CR, Liu JJ, Song YH, Luo ZD. Coupling gene chip analyses and rat genetic variances in identifying potential target genes that may contribute to neuropathic allodynia development. J Neurochem 87:560-573, 2003.

131. Meincke U, Light GA, Geyer MA, Braff DL, Gouzoulis-Mayfrank E. Sensitization and habituation of the acoustic startle reflex in patients with schizophrenia. Psychiatry Res 126:51-61, 2004.

132. Roth WT, Cannon EH. Some features of the auditory evoked response in schizophrenics. Arch Gen Psychiatry 27:466-471, 1972.

133. Crawford TJ, Haeger B, Kennard C, Reveley MA, Henderson L. Saccadic abnormalities in psychotic patients. II. The role of neuroleptic treatment. Psychol Med 25:473-483, 1995.

134. Ludewig K, Geyer MA, Etzensberger M, Vollenweider FX. Stability of the acoustic startle reflex, prepulse inhibition, and habituation in schizophrenia. Schizophr Res 55:129-137, 2002.

135. Siegel SJ, Maxwell CR, Majumdar S, Trief DF, Lerman C, Gur RE, Kanes SJ, Liang Y. Monoamine reuptake inhibition and nicotine receptor antagonism reduce amplitude and gating of auditory evoked potentials. Neuroscience 133:729-738, 2005.

136. Louchart-de la Chapelle S, Levillain D, Menard JF, Van der Elst A, Allio G, Haouzir S, Dollfus S, Campion D, Thibaut F. P50 inhibitory gating deficit is correlated with the negative symptomatology of schizophrenia. Psychiatry Res, 11 July 2005. 